Nathalie Jacobs · Alessandra Mazzoni •

Delia Mezzanzanica • Donatella R.M. Negri •

Olga Valota - Maria I. Colnaghi · Michel P. Moutschen • Jacques Boniver · Silvana Canevari

\title{
Efficiency of T cell triggering by anti-CD3 monoclonal antibodies (mAb) with potential usefulness in bispecific mAb generation
}

Received: 2 January 1997 / Accepted: 6 February 1997

\begin{abstract}
T cell triggering can be achieved by monoclonal antibodies (mAbs) specific for the CD3/TcR complex. In the presence of appropriate costimulation and/or progression factors, such triggering permits the generation of effector cells for immunotherapy protocols involving the redirection of $\mathrm{T}$ cell lysis against tumor cells by mAbs bispecific for anti-CD3/anti-tumor cells (bs-mAbs). Focusing our analysis on the clinically relevant bs-mAb OC/TR, we found that bs-mAbs generated with the same anti tumor specificity, but two other anti-CD3 mAbs, TR66 and OKT3, have the same and a significantly lower lytic potential, respectively, compared with that of OC/TR. To evaluate the relevance of the anti-CD3 component, we examined several anti-CD3 mAbs with respect to binding parameters and the ability to trigger $\mathrm{T}$ lymphocytes. Competitive binding assays suggested that all anti-CD3 mAbs recognized the same or overlapping epitopes, although mAbs BMA030 and OC/TR bound with lower avidity than did $\alpha \mathrm{CD} 3$ (the bivalent anti-CD3 mAb produced by the hybrid hybridoma OC/TR), TR66 and OKT3, as determined by measurement of the affinity constants. In all lymphocyte populations examined, which included resting peripheral blood mononuclear cells (PBMC), activated PBMC and T cell clones, OKT3, BMA033 and OC/TR failed to mobilize $\mathrm{Ca}^{2+}$ without cross-linking, whereas $\alpha \mathrm{CD} 3$, in both murine and murine-human chimeric versions, TR66 and BMA030, did not require cross-linking. The ability to induce CD3 modulation was associated in part with the induction of $\mathrm{Ca}^{2+}$ fluxes. Despite the differences in the behavior of these $\mathrm{mAbs}$ in triggering the events that precede proliferation, all of them ultimately led to expression of the IL-2 receptor and to proliferation in $\mathrm{T}$ cells in the presence of accessory
\end{abstract}

N. Jacobs • M.P. Moutschen • J. Boniver CHU Sart Tilman, Anatomie Pathologique, Liège 1-4000, Belgium

S. Canevari - A. Mazzoni - D. Mezzanzanica - D.R.M. Negri •

O. Valota $\cdot$ M.I. Colnaghi

Division of Experimental Oncology E, Istituto Nazionale Tumori,

Via Venezian 1, I-20133 Milano, Italy

Tel.: (39)-2-2390567; fax (39)-2-2362692 cells. Our data suggest that anti-CD3 mAbs that bind more rapidly (strong $\mathrm{Ca}^{2+}$ mobilizers) and more tightly under physiological conditions are good candidates for retargeting $\mathrm{T}$ cells in the bs-mAb clinical application.

Key words $\mathrm{T}$ cell activation $\cdot \mathrm{Ca}^{2+}$ flux $\cdot$ CD3 modulation $\cdot \mathrm{T}$ cell proliferation $\cdot$ Anti-tumor bs-mAb Retargeting

Abbreviations bs-mAb, bispecific monoclonal antibody; chi: chimeric; m: murine; $\mathrm{IC}_{50}$ : dose of competitor required to inhibit mAb binding by $50 \%$; PBMC, peripheral blood mononuclear cells; r, recombinant; TAA, tumor-associated antigen.

\section{Introduction}

TcR heterodimers provide $\mathrm{T}$ cells with the specificity for cognate recognition of antigen within the $\mathrm{MHC}$, but the cell surface expression and function of the TcR are both dependent on the associated CD3 complex [41]. The physiological TcR-MHC/antigen interaction, together with the cooperative interaction of accessory molecules, leads to clonotypic $\mathrm{T}$ cell activation through several related steps, beginning with second messenger generation and ending with the development of effector functions. The same biochemical events can be engaged in polyclonal $\mathrm{T}$ cell populations by antibodies specific for framework epitopes of the TcR or the invariant chains of the CD3 complex $[3,32]$.

Triggering of any $\mathrm{T}$ cell, irrespective of its fine specificity, by anti-CD3 mAbs has been therapeutically exploited by construction of bispecific mAbs (bs-mAb) in conjunction with a number of different anti-tumor-associated antigen (TAA) mAbs. Engagement and cross-linking of the TcR-CD3 complex alone may lead to a state of $\mathrm{T}$ cell unresponsiveness (anergy) or even to cell death by apoptosis [16]. Thus, adoptive immunotherapy based on the use of anti-CD3/anti-TAA bs-mAbs requires the ex vivo activation 
of $\mathrm{T}$ cells for effective anti-tumor reactions. Properly activated $\mathrm{T}$ lymphocytes that are specifically retargeted to tumor cells by bs-mAbs can lyse tumor cells and inhibit their in vitro growth $[25,31]$. This approach has resulted in eradication of human tumors in xenotransplanted mice [14, 26]. Numerous anti-CD3 mAbs have been used to study the activation of T cells [1, 11, 17, 20, 28-30], but only a few have been used to generate anti-tumor bs-mAbs [26, 31]. Several phase I trials have suggested the clinical potential of anti-tumor/anti-CD3 bs-mAb [2, 4, 8, 9, 40], and at least one phase II trial in ovarian carcinoma patients has demonstrated the benefit of these reagents [6]. Using hybrid hybridomas derived from the fusion of the same antiovarian carcinoma hybridoma with two different anti-CD3 hybridomas (OKT3 and TR66) [10, 38] or immunized spleen cells [10], we evaluated the relevance of the fine binding specificity of the anti-CD3 component of the bs$\mathrm{mAb}$ in redirecting $\mathrm{T}$ cell-induced lysis. Since the three bsmAbs differed in cytolytic potential, the parental anti-CD3 mAbs and some others were examined for their ability to trigger $\mathrm{T}$ lymphocytes activation. Our results show that these mAbs behave differently in triggering the events that precede proliferation, such as $\mathrm{Ca}^{2+}$ mobilization and $\mathrm{CD} 3$ modulation, but all of the mAbs tested ultimately lead to expression of the IL-2 receptor and to proliferation of T cells in the presence of progression factors.

\section{Material and methods}

Anti-CD3 antibodies

BMA030 ( $\left.\mathrm{mIgG}_{2 \mathrm{a}}\right)$ and BMA033 $\left(\mathrm{mIgG}_{3}\right)$ were kindly provided in purified form by Dr. Kurrle (Behringwerke, Marburg, Germany). OKT3 $\left(\mathrm{mIgG}_{2 \mathrm{a}}\right)$ and TR66 $\left(\mathrm{mIgG}_{1}\right)$ hybridomas were obtained from the ATCC (Rockville, Md.) and kindly provided by Dr. A. Lanzavecchia (Basel Institute), respectively. Three anti-ovarian carcinoma/antiCD3 hybrid hybridomas, the trioma OC/TR ( $\left.\mathrm{mIgG}_{1}\right)$ and the quadromas $\mathrm{T} 3 / \mathrm{OC} 1$ (mIgG1/G2a) and T3/OC2 (mIgG1), derived from the fusion of hybridoma MOv18 [15] with spleen cells of a mouse immunized with human T cells and hybridomas OKT3 and TR66, respectively, were also used [10]. OC/TR has been fully characterized and used in preclinical and clinical studies [3, 6, 13, 23]. The mAbs were purified from mouse ascitic fluid or cell culture supernatant by affinity chromatography on insolubilized protein A according to their isotype. The bs-mAbs and, in the case of the mAb produced by the trioma OC/TR, the anti-CD3 bivalent component (referred to below as $\alpha C D 3)$ were fractionated on a hydroxylapatite HPLC column as described elsewhere [23]. Their purity and integrity was confirmed by SDS-PAGE and isoelectrofocusing using the automated microprocessor-driven Phastsystem (Pharmacia LKB Biotechnology, Uppsala, Sweden), by analytical gel filtration, and by FACScan (Becton Dickinson, Erembodegem, Belgium) analysis of the target cells. Chi- $\alpha \mathrm{CD} 3$, obtained by chimerizing the variable regions of the $\alpha \mathrm{CD} 3$ with the human L- and IgG1-constant regions [18], was kindly provided in purified form by Dr. L. Coney (Centocor, Malvern, Pa.) All mAbs were kept at $4^{\circ} \mathrm{C}$ in sterile saline and were used as entire IgG molecules.

\section{Preparation and culture of lymphocytes}

PBMC were obtained from heparinized peripheral blood of healthy adult donors by centrifugation on Lymphoprep (Nycomed, Oslo, Norway), washed three times, and counted. For evaluation of mAb-binding characteristics, PBMC were activated with PHA (Wellcome, Dartford,
UK) $(1 \mu \mathrm{g} / \mathrm{ml})$ and stimulated with $100 \mathrm{U} / \mathrm{ml}$ human recombinant (r) IL-2 (kindly provided by Glaxo Institute for Molecular Biology, Geneva, Switzerland) as already described [22]. For evaluation of $\mathrm{Ca}^{2+}$ fluxes, PBMC were stimulated for 4 days with $50 \mathrm{U} / \mathrm{ml}$ rIL-2 plus $10 \mathrm{ng} / \mathrm{ml} \mathrm{mAb}$ BMA030. Two alloreactive T-cell clones (DM3 and DM13) were used in $\mathrm{Ca}^{2+}$ flux analysis and for evaluation of bs-mAb cytotoxic activity. Both clones were restimulated every 2 weeks with $1 \mu \mathrm{g} / \mathrm{ml}$ PHA and irradiated (3,000 R) allogeneic PBMC and stimulated with rIL-2 $(25 \mathrm{U} / \mathrm{ml})$. The culture medium consisted of RPMI 1640 (Gibco, Ghent, Belgium) supplemented with $1 \%$ non-essential amino acids (Gibco), $1 \mathrm{mM}$ sodium pyruvate (Gibco), $30 \mathrm{U} / \mathrm{ml}$ penicillinstreptomycin (Gibco) and $5 \%$ pooled heat-inactivated human $\mathrm{AB}$ serum.

Assay of bs-mAb cytotoxic activity

Cytotoxicity was determined in a standard 4-h ${ }^{51} \mathrm{Cr}$-release assay. Ovarian carcinoma IGROV1 cells were incubated for $1 \mathrm{~h}$ at $37^{\circ} \mathrm{C}$ with $100 \mu \mathrm{Ci} \mathrm{Na}{ }^{51} \mathrm{CrO}_{4} / 10^{6}$ cells (ICN Biomedicals, Milan, Italy). After washing, cells (5000/well) were seeded in triplicate in U-shaped 96-well plates with DM13 alloreactive T cell clone at an effector-totarget cell ratio of 10:1 and the indicated amount of bs-mAb in a final volume of $0.2 \mathrm{ml} /$ well. After $4 \mathrm{~h}$ of incubation, $0.1 \mathrm{ml} / \mathrm{well}$ of supernatant was withdrawn and radioactivity measured in a $\beta$-counter. Spontaneous release of ${ }^{51} \mathrm{Cr}$, determined in cells incubated with medium alone, was always $<20 \%$. Maximum ${ }^{51} \mathrm{Cr}$ release was measured in cells lysed in 1\% NP-40. SEM of triplicates never exceeded 5-10\%.

Percent specific lysis was calculated as

$100 \times \frac{\text { Experimental release } \mathrm{cpm}-\text { spontaneous release } \mathrm{cpm}}{\text { Maximum release } \mathrm{cpm}-\text { spontaneous release } \mathrm{cpm}}$

\section{Anti-CD3 mAb binding assays}

Based on their sensitivity to labeling procedures, mAbs $\alpha \mathrm{CD} 3$, BMA030, TR66 and OC/TR were labeled with 125I (Amersham, Aylesbury, UK) by lactoperoxidase-catalyzed iodination [12] to a mean specific activity of $8.4 \mu \mathrm{Ci} / \mathrm{g}$. OKT3 was labeled by the Bolton-Hunter method to a final specific activity of $4.4 \mu \mathrm{Ci} / \mathrm{g}$.

The $K_{a f f}$ and number of sites recognized by the anti-CD3 mAbs were evaluated by Scatchard analysis. Activated PBMC $(2 \times 105 /$ well in $0.05 \mathrm{ml}$ RPMI-1640 plus $1 \% \mathrm{FCS}$ ) were incubated for $3 \mathrm{~h}$ at $0^{\circ} \mathrm{C}$ with serial dilutions of $125 \mathrm{I}-\mathrm{mAb}$. After three washes with cold buffer (PBS plus BSA, $0.03 \% \mathrm{w} / \mathrm{v}$ ), cell-bound radioactivity was measured directly in a counter. Background was determined in the presence of a 100-fold excess of cold mAb. For competition assays, activated PBMC were seeded at $2 \times 10^{5}$ cells per well in $0.05 \mathrm{ml}$ of RPMI-1640,1\% FCS, in the presence of a fixed amount of $125 \mathrm{I}-\mathrm{mAb}\left(5 \times 10^{5} \mathrm{cpm} /\right.$ well $)$ and different concentrations of competitor. After incubation for $3 \mathrm{~h}$ at $0^{\circ} \mathrm{C}$ or $37^{\circ} \mathrm{C}$, cells were washed three times and assessed directly for radioactivity in a $\gamma$-counter. The dose of cold competitor required to inhibit radiolabeled $\mathrm{mAb}$ binding by $50 \%$ ( $\mathrm{IC}_{50}$ ) was extrapolated from dose-response curves.

\section{Assays of cytoplasmic free $\mathrm{Ca}^{2+}$}

After addition of $3 \mu \mathrm{l}$ of $20 \%$ (v/v) Plutronic F-127 (Molecular Probes, Eugene, Ore.), lymphocytes (107 in $1 \mathrm{ml}$ of Hank's solution, Gibco) were loaded with $3 \mathrm{M}$ fluo-3/AM (Molecular Probes) and incubated for $20 \mathrm{~min}$ in the dark at $37^{\circ} \mathrm{C}$. After dilution (1/5) in HBSS containing $1 \%$ FCS and a further $45 \mathrm{~min}$ incubation at $37^{\circ} \mathrm{C}$, cells were washed three times and resuspended at a concentration of $1-2 \times 10^{6}$ cells $/ \mathrm{ml}$ in Hepes-buffered saline (Sigma, St. Louis, Mo.). Before flow cytometry, cells were incubated for $10 \mathrm{~min}$ at $37^{\circ} \mathrm{C}$ in a water bath. Cells were stimulated by anti-CD3 mAbs $(2 \mu \mathrm{g} / \mathrm{ml})$ and analyzed on a Facscan. In all experiments, $8 \mu \mathrm{g} / \mathrm{ml}$ of rabbit anti-mouse $\mathrm{Ig}$ (Chemicon, Temecula, Calif.) was added to crosslink the prebound anti-CD3 mAb before reanalysis on a FACScan. Events were acquired and analyzed with Lysis II software. 
Proliferation assays

Responder donors PBMC able to bind and to proliferate equally well in the presence of anti-CD3 $\operatorname{IgG}_{1}$ and $\mathrm{IgG}_{2 \mathrm{a}} \mathrm{mAbs}[20]$ were selected. PBMC $\left(1.25 \times 10^{6}\right.$ cells $\left./ \mathrm{ml}\right)$ were cultured for 4 days in the presence of $50 \mathrm{U} / \mathrm{ml}$ of human rIL-2. On days 2 and 4 of culture, cells were plated in triplicate in 96-well U-bottomed plates at $10^{4}$ cells/well in $200 \mu \mathrm{l}$ of medium. ${ }^{3} \mathrm{H}$-Thymidine $(25 \mu \mathrm{l}, 0.4 \mathrm{mCi}$, Dupont NEN, Dreieich, Germany) was added to each well, and after $4 \mathrm{~h}$ cells were harvested with a cell harvester (Skatron, Lier, Norway) on glassfiber filters, whereupon ${ }^{3} \mathrm{H}$-thymidine incorporation was determined by scintillation counting (1500 TriCarb Packard).

\section{Immunofluorescence and flow cytometry}

PBMC stimulated for 1-4 days with anti-CD3 mAb and rIL-2 $\left(0.5 \times 10^{6}\right.$ cells $)$ were incubated on ice with $25 \mu \mathrm{l}$ of goat anti-mouse Ig-FITC (Immunotech, Marseille, France), anti-CD3-FITC (B-B11, IQP, Groningen, The Netherlands), or anti-CD25-PE (Dako, Denmark). After washing, cells were analyzed for fluorescence intensity on a Facstar $^{+}$(Becton Dickinson) with Lysis II software.

\section{Statistical analysis}

Data were analyzed using the Student's $t$-test, Mann-Whitney or an ANOVA test (Instat, GraphPad software).

\section{Results}

Anti-ovarian carcinoma/anti-CD3 bs-mAb induce different cytotoxicity

We showed previously that T3/OC1 (MOv18×OKT3) mediates a lytic activity lower than that induced by $\mathrm{OC} /$ TR $(M O v 18 \times \alpha C D 3)$ [13]. Using a different $\mathrm{T}$ cell clone, we confirmed that the T3/OC1 was less efficient than $\mathrm{OC} /$ TR and T3/OC2 (MOV18×TR66) bs-mAbs, which are raised with different anti-CD3 specificities, in retargeting (Fig. 1). Indeed, in each test and at both bs-mAb concentrations (100 and $1 \mathrm{ng} / \mathrm{ml})$, the lysis mediated by the bs$\mathrm{mAb}$ with OKT3 was significantly lower.

Anti-CD3 mAbs have different binding properties

To determine whether the affinity and avidity of different anti-CD3 mAbs might determine the different cytotoxic potential of bs-mAb, binding properties of the three parental anti-CD3 mAbs ( $\alpha \mathrm{CD} 3$, OKT3, TR66), another antiCD3 mAb (BMA030) and bs-mAb OC/TR were assessed by Scatchard analysis and competition assays. The experiments were initially performed at $0^{\circ} \mathrm{C}$ to ensure a high binding level. Scatchard analysis of the binding data revealed comparable $\mathrm{K}_{\mathrm{aff}}$ values for $\alpha \mathrm{CD} 3\left(7.4 \times 10^{8} \mathrm{M}^{-1}\right)$, OKT3 $\left(7 \times 10^{8} \mathrm{M}^{-1}\right)$ and TR66 $\left(3.6 \times 10^{-8} \mathrm{M}\right)$, and $4-10$ times lower values for BMA030 $\left(0.8 \times 10^{8} \mathrm{M}^{-1}\right)$ (Fig. 2) and OC/TR $\left(1 \times 10^{8} \mathrm{M}\right)$ (not shown). Competitive binding assays at $0{ }^{\circ} \mathrm{C}$ suggested that all anti-CD3 mAbs recognized the same or overlapping epitopes (see Fig. 3 for a representative experiment of $\alpha \mathrm{CD} 3$ competition), although OC/ TR and BMA030 bound with lower avidity, than $\alpha \mathrm{CD} 3$, TR66 and OKT3.

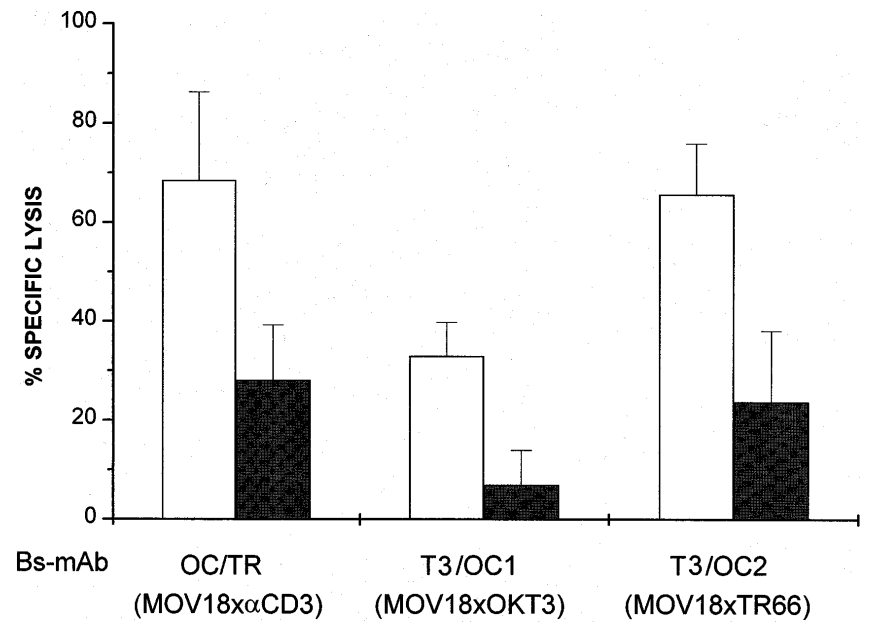

Fig. 1 Anti-ovarian carcinoma/anti-CD3 bs-mAb redirected lysis of IGROV1 cells by a CTL clone in a 4-h ${ }^{51} \mathrm{Cr}$-release assay. DM13 CTL clone cells were used at an effector to-target cell ratio of 10:1 in the presence of $100 \mathrm{ng} / \mathrm{ml} \square$ or $1 \mathrm{ng} / \mathrm{ml} \square$ of whole bs-mAb. Lysis in the absence of bs-mAb or in the absence of CTL was less than 5\%. Data are reported as mean $\pm S E M$ of $3-5$ independent experiments

Competition experiments performed at $37^{\circ} \mathrm{C}$ to evaluate binding properties in physiological conditions (Fig. 3) revealed an inhibition induced by each anti-CD3 that resembled the pattern observed at $0^{\circ} \mathrm{C}$, despite an increase in the $\mathrm{IC}_{50}$ values, which was particularly evident for BMA030 $\left(\mathrm{IC}_{50}=12.9 \mathrm{nM}\right.$ at $0^{\circ} \mathrm{C}$ and $264 \mathrm{nM}$ at $37^{\circ} \mathrm{C}$ ) and OKT3 $\left(\mathrm{IC}_{50}=8.5\right.$ at $0^{\circ} \mathrm{C}$ and $794 \mathrm{nM}$ at $\left.37^{\circ} \mathrm{C}\right)$.

Stimulation by different anti-CD3 mAb induces different calcium fluxes

The calcium response after stimulation with seven different anti-CD3 mAb without further cross-linking was studied on different cell populations: resting PBMC, BMA030-activated $\mathrm{PBMC}$ and $\mathrm{CD}^{+}$or $\mathrm{CD} 4+\mathrm{T}$ cell clones (Table 1$)$. In all experiments, BMA030, TR66, $\alpha \mathrm{CD} 3$ and chi- $\alpha \mathrm{CD} 3$

Table 1 Calcium response in different lymphocyte preparations after stimulation with different anti-CD3 $\mathrm{mAb}$

\begin{tabular}{|c|c|c|c|c|}
\hline \multirow{3}{*}{$\begin{array}{l}\text { Anti-CD3 } \\
\mathrm{mAb}\end{array}$} & \multicolumn{4}{|c|}{ Calcium response ${ }^{a}$ in } \\
\hline & \multicolumn{2}{|l|}{ PBMC } & \multicolumn{2}{|l|}{$\mathrm{T}$ cell clones } \\
\hline & Resting & $\begin{array}{l}\text { BMA030- } \\
\text { activated }\end{array}$ & $\begin{array}{l}\text { DM13 } \\
\text { CD8 }^{+}\end{array}$ & $\begin{array}{l}\text { DM3 } \\
\text { CD4+ }\end{array}$ \\
\hline BMA030 & $193 \pm 21(5)^{\mathrm{b}}$ & $171 \pm 24(5)$ & $387 \pm 83(2)$ & $148 \pm 23(4)$ \\
\hline TR66 & $186 \pm 13(6)$ & $172 \pm 17(4)$ & $384 \pm 51$ & $147 \pm 19$ \\
\hline OKT3 & $122 \pm 6(5)$ & $99 \pm 4(3)$ & $127 \pm 22(2)$ & $90 \pm 4(3)$ \\
\hline OC/TR & $125 \pm 9(4)$ & $102 \pm 4(4)$ & $171 \pm 12(2)$ & $99 \pm 6(4)$ \\
\hline$\alpha \mathrm{CD} 3$ & $218 \pm 11(2)$ & 278 & 455 & $163 \pm 17(2)$ \\
\hline chi- $\alpha \mathrm{CD} 3$ & $198 \pm 11(3)$ & - & 355 & $137 \pm 22(2)$ \\
\hline BMA033 & 118 & 98 & 96 & $96 \quad$ (1) \\
\hline
\end{tabular}

a Evaluated as free cytoplasmic $\mathrm{Ca}^{2+}$ levels in fluo-3-loaded cells. Data are reported as: (mean fluorescence after addition of anti-CD3/ mean fluorescence of baseline $) \times 100$

b Mean \pm SD (number of experiments) 

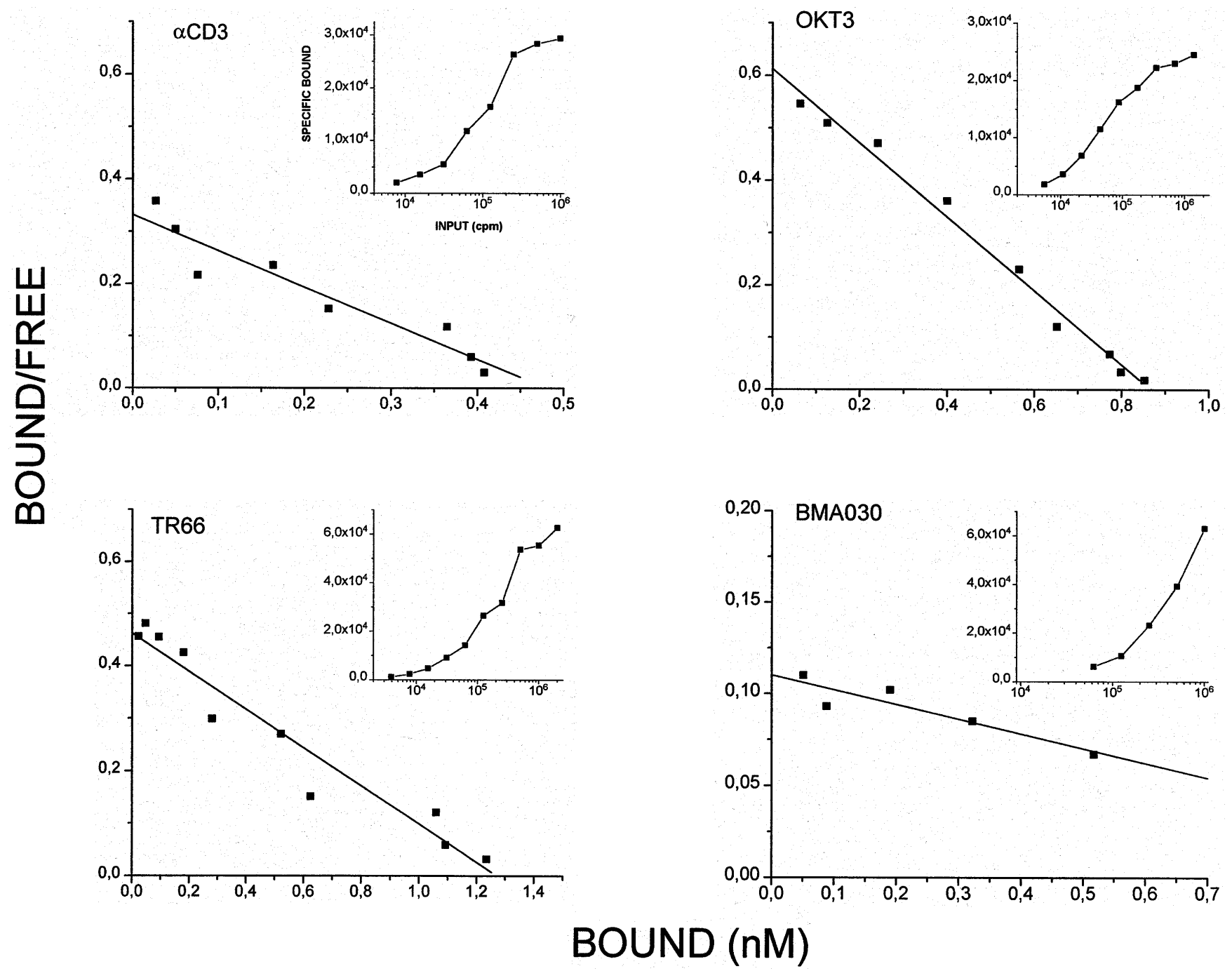

mAbs induced calcium mobilization, whereas OKT3, BMA033 and OC/TR generated only low or no detectable calcium fluxes. Figure 4A shows representative FACS profiles on resting PBMC. A higher $(6 \mu \mathrm{g} / \mathrm{ml})$ or lower $(10 \mathrm{ng} / \mathrm{ml})$ concentration of OKT3 did not generate a $\mathrm{Ca}^{2+}$ response at the levels obtained with TR66 or BMA030 (data not shown). The extent of $\mathrm{Ca}^{2+}$ increase was dependent on the $\mathrm{T}$ cell type and activation status, and the responses were highest in the $\mathrm{CD} 8+\mathrm{T}$ cell clone, but the various anti-CD3 mAb gave a similar cline of response with all the cell types used. After cross-linking with rabbit antimouse or anti-human $\mathrm{IgG}$, the $\mathrm{Ca}^{2+}$ response became comparable for all anti-CD3 mAbs (Fig. 4B). By comparing monovalent OC/TR with the murine and the chimeric versions of the bivalent parental $\alpha \mathrm{CD} 3$ and by cross-linking with anti-mouse or anti-human Ig, we confirmed that binding valency plays a role in inducing $\mathrm{Ca}^{2+}$ mobilization. However, bridging to monocytes present in the PBMC population by $\mathrm{mAb}$ or bs-mAb Fc portion did not induce $\mathrm{Ca}^{2+}$ mobilization, perhaps because bridging occurs later or because the number of monocytes is insufficient.
Fig. 2 Scatchard plots of 125I-anti-CD3 mAb binding on human activated PBMC. Inset binding plots. Statistical analysis of the curves: $\alpha \mathrm{CD} 3, R^{2}=0.95195 \quad(P<0.0001) ;$ OKT3 $R^{2}=0.99451 \quad(P<0.0001)$; TR66, $R^{2}=0.97066(P<0.0001)$; BMA030 $R^{2}=0.9188(P<0.05)$

\section{OC/TR and BMA033 do not induce CD3 modulation}

Modulation of the CD3 molecule was evaluated on resting PBMC of responder donors (see "Materials and methods"). Cells were cultured in the presence of rIL-2 and soluble anti-CD3 $\mathrm{mAb}(10 \mathrm{ng} / \mathrm{ml})$ and analyzed for CD3 expression and the residual presence of the anti-CD3 $\mathrm{mAb}$ on the cell surface from day 1 to day 4 (Table 2). At the concentrations tested, there was no competition between the anti-CD3 used for detection and the anti-CD3 mAb used for stimulation (data not shown). Down-regulation of CD3 was observed after $24 \mathrm{~h}$ stimulation with TR66, BMA030, $\alpha \mathrm{CD} 3$ and chi$\alpha \mathrm{CD} 3$, but not with OC/TR or BMA033; OKT3 induced intermediate down-regulation (Fig. 5A). The modulation pattern by the mAbs was highly reproducible, except for BMA030, with PBMC from different donors (Table 2). CD3 expression returned to initial values on day 4 , despite the continuous presence of the anti-CD3 mAbs during the 
Table 2 CD3 modulation induced by different anti-CD3 mAbs on PBMC

\begin{tabular}{lllll}
\hline & \multicolumn{4}{l}{ CD3 expression at daya } \\
\cline { 2 - 5 } Culture condition & 1 & 2 & 3 & 4 \\
\hline Control & 1.00 & 1.00 & 1.00 & 1.00 \\
IL-2 & $1.01 \pm 0.08$ & $1.07 \pm 0.09$ & $1.25 \pm 0.28$ & $1.06 \pm 0.09$ \\
IL-2 + BMA030 & $0.52 \pm 0.33$ & $0.71 \pm 0.53$ & $1.03 \pm 0.65$ & $1.15 \pm 0.54$ \\
IL-2 + TR66 & $0.30 \pm 0.06$ & $0.45 \pm 0.28$ & $1.07 \pm 0.17$ & $0.91 \pm 0.31$ \\
IL-2 + OKT3 & $0.58 \pm 0.16$ & $0.74 \pm 0.18$ & $1.15 \pm 0.23$ & $1.16 \pm 0.30$ \\
IL-2 + OC/TR & $0.91 \pm 0.10$ & $1.06 \pm 0.11$ & $1.39 \pm 0.33$ & $1.25 \pm 0.19$ \\
IL-2 + $\alpha$ CD3 & $0.22 \pm 0.12$ & $0.74 \pm 0.59$ & $1.11 \pm 0.83$ & $1.19 \pm 0.54$ \\
IL-2 + chi $\alpha-C D 3$ & $0.29 \pm 0.07$ & $0.46 \pm 0.127$ & $1.08 \pm 0.18$ & $1.27 \pm 0.22$ \\
IL-2 + BMA033 & $0.94 \pm 0.05$ & $0.92 \pm 0.06$ & $1.20 \pm 0.30$ & $1.28 \pm 0.22$ \\
\hline
\end{tabular}

a Data are mean \pm SEM of three independent experiments and are expressed as: mean fluorescence in presence of anti-CD3/mean fluorescence in control cells

induction period. The anti-CD3 mAbs were detectable on the cell surface by staining with an anti-mouse or antihuman Ig-FITC on day 1 (Fig. 5B).

All anti-CD3 mAbs induce cell proliferation and IL-2 receptor expression

Under the culture conditions described above, the levels of cell activation induced by the soluble anti-CD3 mAb were compared by measuring cell proliferation and the expression of the IL-2 receptor (CD25) in three independent experiments. On day 2, a proliferative response was observed with all anti-CD3 mAbs, but the bs-mAb OC/TR was significantly less potent in inducing proliferation than was its parental $\alpha \mathrm{CD} 3$ (Fig. 6A). After 4 days of culture, a similar proliferative response was observed for all anti-CD3 mAbs (Fig. 6B). Results were similar for the expression of the IL-2 receptor. A significantly lower percentage of $\mathrm{CD} 25^{+}$cells was observed in culture with OC/TR on day 2 (Fig. 6A), but this percentage increased to near that with other anti-CD3 mAbs on day 4 (Fig. 6B).

\section{Discussion}

The significant clinical potential of bs-mAbs containing anti-CD3 in retargeting $\mathrm{T}$ cell cytotoxicity against tumor cells led us to evaluate the possible correlation between their cytotoxic efficiency and the binding and activating potential of the parental anti-CD3 mAbs. We focused our analysis on the bs-mAb OC/TR, which is now being used in clinical trials [4-6]. Comparison of the parental $\mathrm{mAb}$ $\alpha C D 3$ with several other anti-CD3 mAbs showed that all the tested anti-CD3 mAbs ultimately led to full $\mathrm{T}$ cell activation in a system in which progression factors are provided. This was true despite an apparent inability of $\mathrm{OC} /$ TR, OKT3 and BMA033 to trigger $\mathrm{Ca}^{2+}$ mobilization. Recently, Zhu and Carter [42] demonstrated a direct correlation between antigen-binding efficiency and late $\mathrm{T}$ cell activation events in a panel of humanized variants of the anti-CD3 mAb UCHT1. We analyzed the influence of anti-
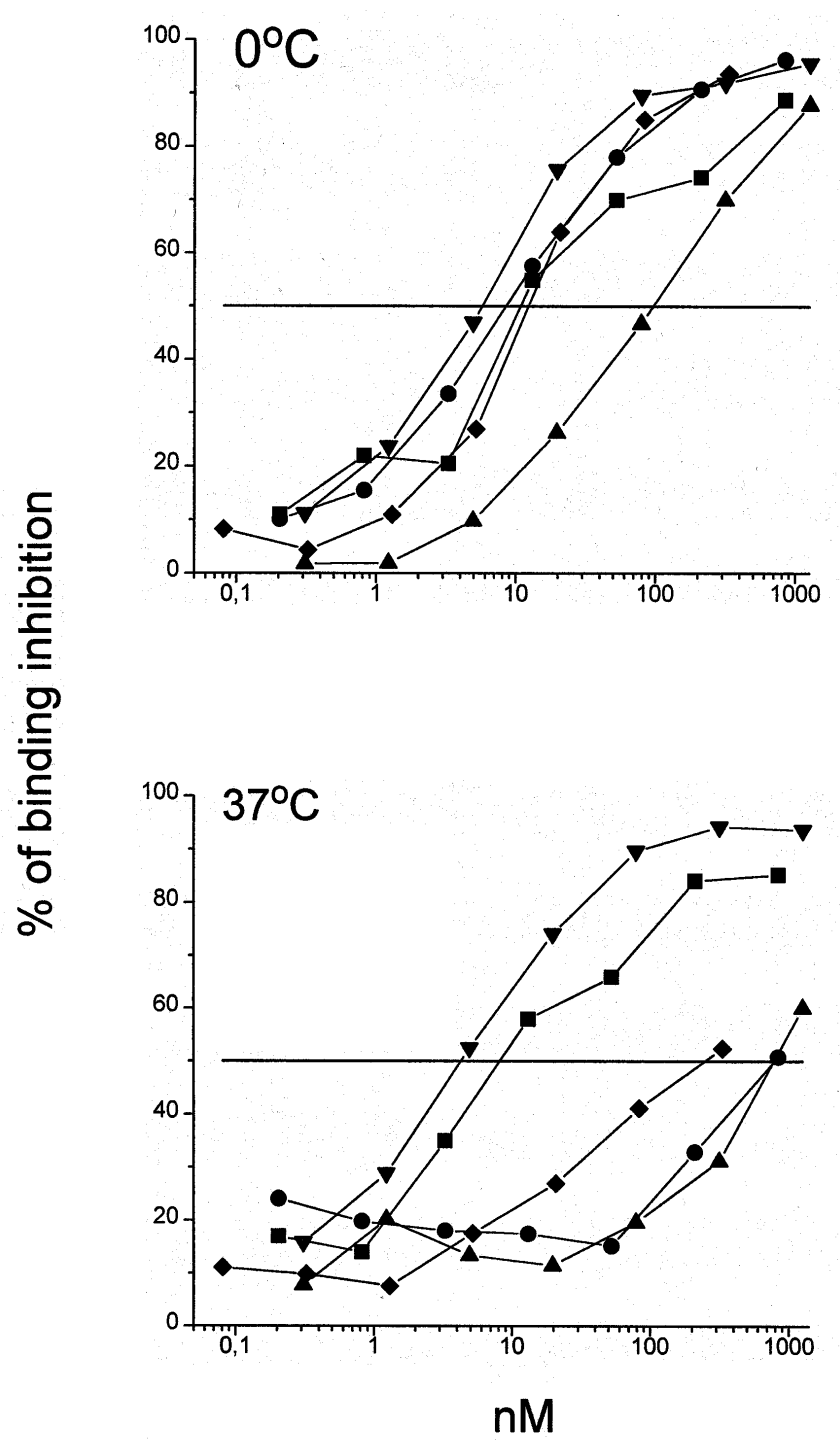

Fig. 3 Binding properties of different anti-CD3 mAb. ${ }^{125 I-\alpha C D} 3 \mathrm{mAb}$ $(10 \mathrm{nM})$ binding to human activated PBMC competed with titrated doses of unlabeled homologous or heterologous $\mathrm{mAb}$, as described in Materials and methods for each radiolabeled $\mathrm{mAb}$ at $0^{\circ} \mathrm{C}$ or at $37^{\circ} \mathrm{C}$. Competing mAb: TR66 (䍒; OKT3 $(\boldsymbol{\bullet})$; $\alpha \mathrm{CD} 3(\boldsymbol{\nabla})$; BMA030 $(\bullet)$; OC/TR $(\boldsymbol{\Delta})$. Data are representative of the experiments performed with radiolabeled TR66, OKT3, BMA030 and OC/TR with similar results

CD3 mAb-binding parameters on early ( $\mathrm{Ca}^{2+}$ mobilization) and intermediate-late (CD3 modulation, CD25 expression and proliferation) events.

Our use of the calcium probe fluo- 3 in flow cytometry to measure the increase in cytoplasmic $\mathrm{Ca}^{2+}$ [37] permitted a semi-quantitative evaluation with clear-cut advantages over spectrofluorimetry. Previous studies, conducted mainly with probes that require ultraviolet light $[1,7,11,17,20$, 24, 27-30], have led to conflicting conclusions about a requirement for cross-linking and/or bridging of the TcRCD3 complex in increasing the cytosolic $\mathrm{Ca}^{2+}$ concentration. Several variables, such as the type of T cell population studied or the concentration, fine binding specificity, binding affinity or valency of the mAb, might account for the discrepant results. 

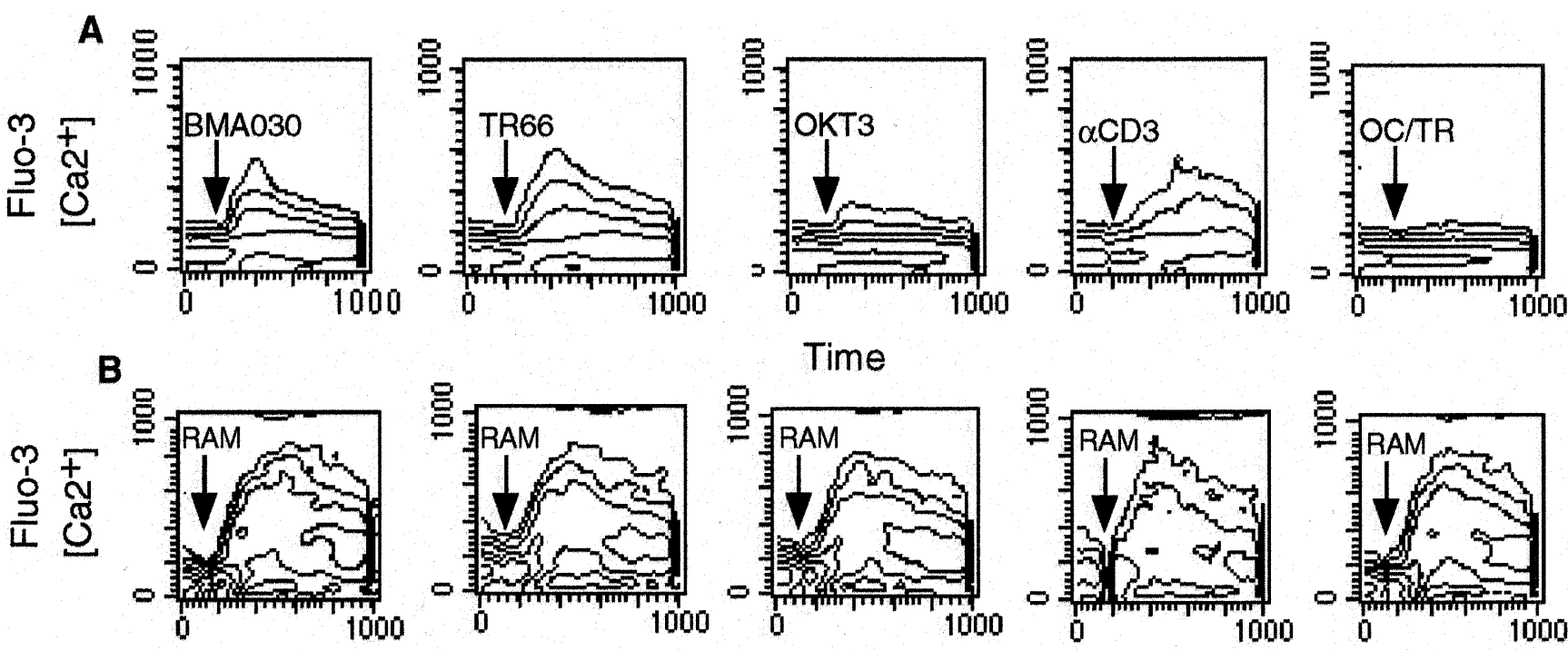

Time
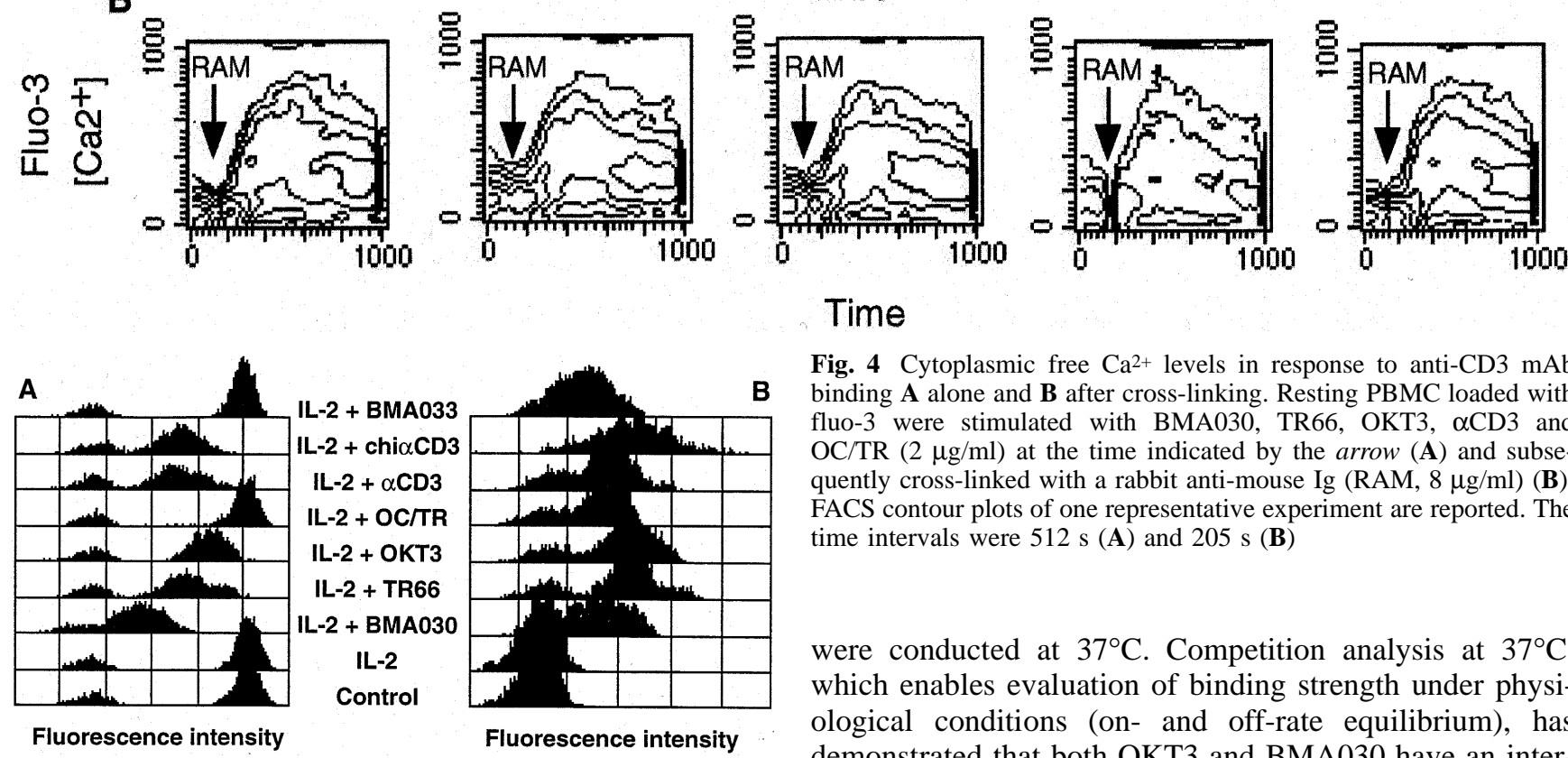

Time

Fig. 4 Cytoplasmic free $\mathrm{Ca}^{2+}$ levels in response to anti-CD3 mAb binding $\mathbf{A}$ alone and $\mathbf{B}$ after cross-linking. Resting PBMC loaded with fluo-3 were stimulated with BMA030, TR66, OKT3, $\alpha \mathrm{CD} 3$ and OC/TR $(2 \mu \mathrm{g} / \mathrm{ml})$ at the time indicated by the arrow (A) and subsequently cross-linked with a rabbit anti-mouse Ig (RAM, $8 \mu \mathrm{g} / \mathrm{ml})(\mathbf{B})$. FACS contour plots of one representative experiment are reported. The time intervals were $512 \mathrm{~s} \mathrm{(A)}$ and $205 \mathrm{~s} \mathrm{(B)}$

Fig. 5A, B Degree of CD3 modulation by different anti-CD3 mAbs. A After 1 day of culture in medium alone (control), or in the presence of rIL-2 or rIL-2 + anti-CD3 mAbs (10 ng/ml), CD3 expression was measured using an anti-CD3-FITC mAb. B Staining cells with FITCgoat anti-mouse Ig or anti-human Ig in the case of chi- $\alpha \mathrm{CD} 3$ showed residual anti-CD3 mAb used for the stimulation. Data are from a single experiment representative of three performed with PBMC from different donors (see Table 2)

All of our anti-CD3 mAbs competed with each other in binding assays, and the amounts required at $0^{\circ} \mathrm{C}$ to obtain the same inhibition were clearly related to their binding affinity. These data imply that the mAbs tested are directed to the same or spatially close epitopes. Previous analysis [34] identified at least three epitope groups on human CD3 through which $\mathrm{T}$ cell activation by anti-CD3 mAb can proceed. OKT3, TR66 and BMA030, which belong to the same CD3 recognition group but bind with a different avidities, differ in their ability to promote $\mathrm{Ca}^{2+}$ mobilization. Our data suggest that the fine binding specificity of anti-CD3 mAb per se plays only a minor part in triggering early activation events, although any firm conclusions await further structure-function analyses.

No clear correlation between the ability to trigger $\mathrm{Ca}^{2+}$ mobilization and $\mathrm{K}_{\mathrm{aff}}$ values was observed, at least in the cases of OKT3 and BMA030. However, our $\mathrm{K}_{\text {aff }}$ determinations, like most of those reported in the literature, were performed at $0-4{ }^{\circ} \mathrm{C}$, whereas $\mathrm{Ca}^{2+}$ mobilization studies

were conducted at $37^{\circ} \mathrm{C}$. Competition analysis at $37^{\circ} \mathrm{C}$, which enables evaluation of binding strength under physiological conditions (on- and off-rate equilibrium), has demonstrated that both OKT3 and BMA030 have an intermediate ability to compete with the $125 \mathrm{I}-\alpha \mathrm{CD} 3$ binding, which was less than the competition exerted by TR66 and homologous $\mathrm{mAb}$.

OKT3 and BMA033 mAbs and OC/TR bs-mAb that were virtually unable to promote $\mathrm{Ca}^{2+}$ mobilization during the first minutes of incubation were also less able or at least slower to promote the modulation of CD3 molecules and expression of CD25. However, all of the mAbs and the bs$\mathrm{mAb}$ OC/TR ultimately induced proliferation, although with a slower kinetics. These data indicate that early $\mathrm{Ca}^{2+}$ mobilization is not a sufficient predictor of final activating ability and that full $\mathrm{T}$ cell activation can occur even in the absence of a detectable $\mathrm{Ca}^{2+}$ increase, due possibly to persistent but undetectable $\mathrm{Ca}^{2+}$ mobilization, or to the activation of another signal transduction pathway. The requirement for TcR/CD3 cross-linking in T cell activation is difficult to extrapolate to the physiological interaction between the TcR and the MHC-peptide complex displayed on the surface of antigen-presenting cells. Indeed, this interaction takes place with as few as 100 complexes and has low affinity and a high off-rate [35]. A model of TcR serial triggering was recently proposed [36] according to which the high off-rate of the TcR is instrumental because it allows a single peptide-MHC complex to engage many TcRs in successive rounds of ligation, triggering and dissociation. According to this model, a higher affinity could result in less stimulation because the lower off-rate may 

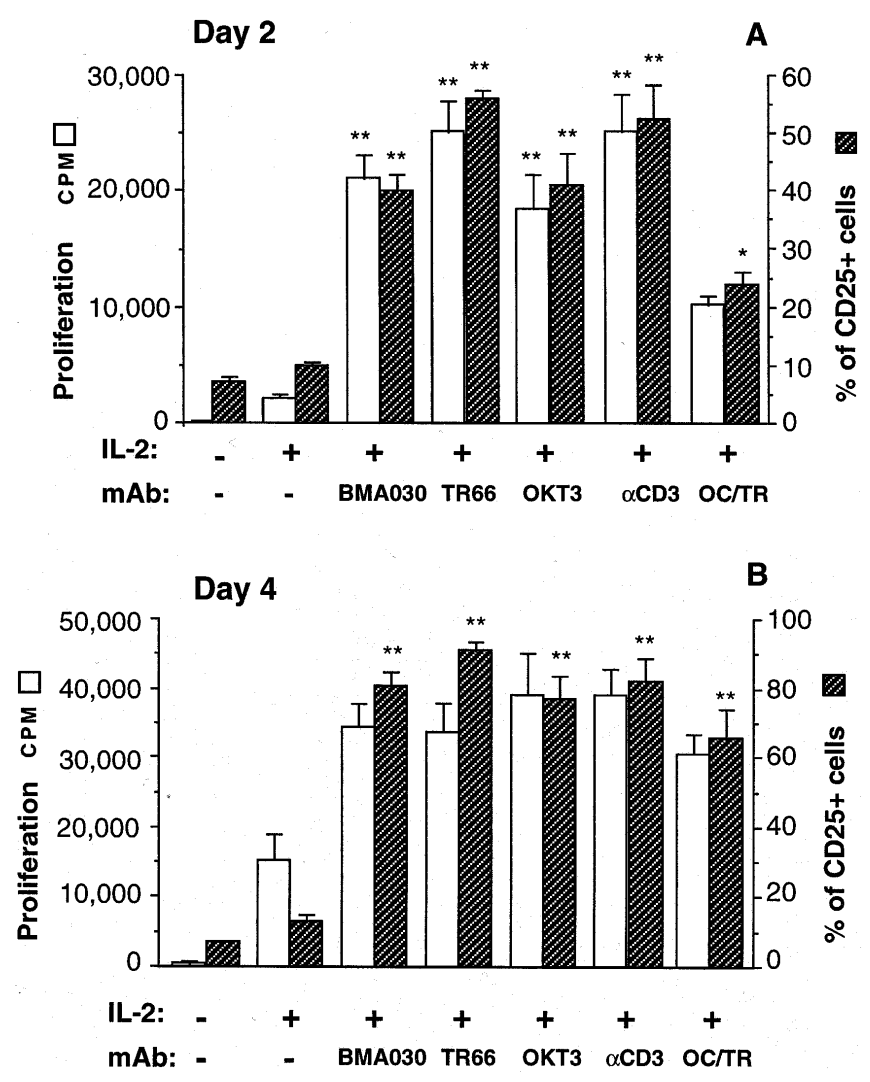

Fig. 6A, B T cell proliferation and $\mathrm{CD} 25$ expression after stimulation with different anti-CD3 mAb. On days 2 (A) and 4 (B) of culture, proliferation was measured by $4-\mathrm{h}$ 3 $\mathrm{H}$-thymidine incorporation (open bars), and the percentage of $\mathrm{CD} 25^{+}$cells (hatched bars) was measured by flow cytometry. Data are the mean \pm SEM of three independent experiments

prevent $\mathrm{TcR}$ reusage. In the case of surrogate antigenic stimulation through anti-CD3 mAbs, the number of concurrent interactions is 1000 times that between the TcR and the MHC-peptide complex. Moreover, TcR signaling characteristically requires that $\mathrm{Ca}^{2+}$ mobilization be sustained for at least $30 \mathrm{~min}$ to induce proliferation and cytokine production [21, 39]. Thus, high binding affinity of anti-CD3 mAbs might not be detrimental, provided that their off-rates are low enough to sustain prolonged $\mathrm{Ca}^{2+}$ mobilization.

In conclusion, we suggest that the best candidates for anti-tumor/anti-CD3 bs-mAb generation are anti-CD3 mAbs, such as $\alpha \mathrm{CD} 3$ and TR66, which bind rapidly (strong $\mathrm{Ca}^{2+}$ mobilizers) and tightly (good competitors at $37^{\circ} \mathrm{C}$ ) under physiological conditions. These mAbs, even in monovalent form, as in the bs-mAb configuration, can be expected to promote and sustain full activation in vivo. Indeed, the higher in vitro cytolytic potential of bs-mAb generated with CD3 and TR66 than of anti-TAA/OKT3 bs$\mathrm{mAb}$ [13] (present report) supports this prediction. On the other hand, the in vivo use of bs-mAb with high promoting ability must be considered with caution in light of the finding that $\mathrm{F}\left(\mathrm{ab}^{\prime}\right)_{2}$ of the OC/TR bs-mAb, when injected i.v. even at dose of $0.2 \mathrm{mg}$, induced a generalized in vivo activation with severe side effects [2, 33] similar to those induced by $5 \mathrm{mg}$ of OKT3 [19]. Thus, treatment protocols with autologous ex vivo-activated lymphocytes coated with OC/TR must be appropriately designed [5] to avoid toxicity while retaining maximum anti-tumor bs-mAb retargeting potential.

Acknowledgements This work was supported in part by the Belgian Fund for Medical Scientific Research, the Centre anticancéreux près $1^{\prime}$ Université de Liège (CAC), CNR-ACRO and AIRC/FIRC. N. Jacobs is supported by a grant from the Léon Fredericq Fundation and an EMBO fellowship. M.P. Moutschen is a Senior Research Assistant of the National Fund for Scientific Research. We thank L. Mameli for manuscript preparation.

\section{References}

1. Blank-Voorthuis CJAC, Braakman E, Ronteltap CPM, Tilly BC, Sturm E, Warnaar SO, Bolhuis RLH (1993) Clustered CD3/TCR complexes do not transduce activation signals after bispecific monoclonal antibody-triggered lysis by cytotoxic $\mathrm{T}$ lymphocytes via CD3. J Immunol 151:2904

2. Boerman TJG, Massuger OC, Schijf CPT, Claessens RAMJ, Corstens FHM (1996) Pharmacokinetics, biodistribution and biological effects of intravenously administered bispecific monoclonal antibody $\mathrm{OC} / \mathrm{TR} \mathrm{F}\left(\mathrm{ab}^{\prime}\right)_{2}$ in ovarian carcinoma patients. Int $\mathrm{J}$ Cancer 66:477

3. Bolhuis RLH, Van de Griend RJ (1985) PHA induced proliferation and cytolytic activity in T3+, but not in T3- cloned T lymphocytes, requires the involvement of the T3 antigen for signal transmission. Cell Immunol 93:46

4. Bolhuis RLH, Lamers CHJ, Goey HS, Eggermont AMM, Trimbos JB, Stoter G, Lanzavecchia A, Di Re E, Miotti S, Raspagliesi F, Rivoltini L, Colnaghi MI (1992) Adoptive immunotherapy of ovarian carcinoma with Bs-MAb targeted lymphocytes. A multicenter study. Int J Cancer 7:78

5. Canevari S, Mezzanzanica D, Mazzoni A, Negri DRM, Ramakrishna V, Bolhuis RLH, Colnaghi MI, Bolis G (1995) Bispecific antibody targeted $\mathrm{T}$ cell therapy of ovarian cancer: clinical results and future directions. J Hematother 4:423

6. Canevari S, Stoter G, Arienti F, Bolis G, Colnaghi MI, Di Re E, Eggermont AMM, Goey SH, Gratama JW, Lamers CHJ, Nooy MA, Parmiani G, Raspagliesi F, Ravagnani F, Scarfone G, Trimbos JB, Warnaar SO, Bolhuis RLH (1995) Regression of advanced ovarian carcinoma by intraperitoneal treatment with autologous Tlymphocytes retargeted by a bispecific monoclonal antibody. J Natl Cancer Inst 87:1463

7. Davis LS, Wacholtz MC, Lipsky PE (1989) The induction of T cell unresponsiveness by rapidly modulating CD3. J Immunol $142: 1084$

8. De Gast GC, Haagen I-A, Van Houten AA, Klein SC, Duits AJ, De Weger RA, Vroom TM, Clark MR, Phillips J, Van Dijk AJG, De Lau WBM, Bast BJEG (1995) CD8 T cell activation after intravenous administration of CD3 CD19 bispecific antibody in patients with non-Hodgkin lymphoma. Cancer Immunol Immunother 40:390

9. Kroesen BJ, Buter J, Sleijfer DT, Janssen RAJ, Van der Graaf WTA, The TH, de Leij L, Mulder NH (1994) Phase I study of intravenously applied bispecific antibody in renal cell cancer patients receiving subcutaneous interleukin 2. Br J Cancer 70:652

10. Lanzavecchia A, Scheidegger D (1987) The use of hybrid hybridomas to target human cytotoxic T lymphocytes. Eur J Immunol 17:105

11. Ledbetter JA, June CH, Martin PJ, Spooner CE, Hansen JA, Meier KE (1986) Valency of CD3 binding and internalization of the CD3 cell-surface complex control $\mathrm{T}$ cell responses to second signals: distinction between effects on protein kinase $\mathrm{C}$, cytoplasmic free calcium, and proliferation. J Immunol 136:3945

12. Marchalonis JJ (1969) An enzymatic method for the trace iodination of immunoglobulin and other proteins. Biochem J 113:299 
13. Mezzanzanica D, Canevari S, Ménard S, Pupa SM, Tagliabue E, Lanzavecchia A, Colnaghi MI (1988) Human ovarian carcinoma lysis by cytotoxicity $\mathrm{T}$ cells targeted by bispecific monoclonal antibodies: analysis of the antibody components. Int $\mathrm{J}$ Cancer 41:609

14. Mezzanzanica D, Garrido MA, Neblock DS, Daddona PE, Andrew SM, Zurawski VR Jr, Segal DM, Wunderlich JR (1991) Human Tlymphocytes targeted against an established human ovarian carcinoma with a bispecific $\mathrm{F}\left(\mathrm{ab}^{\prime}\right)_{2}$ antibody prolong host survival in a murine xenograft model. Cancer Res 51:5716

15. Miotti S, Canevari S, Ménard S, Mezzanzanica D, Porro G, Pupa SM, Regazzoni M, Tagliabue E, Colnaghi MI (1987) Characterization of human ovarian carcinoma-associated antigens defined by novel monoclonal antibodies with tumor-restricted specificity. Int J Cancer 39:297

16. Mueller DL, Jenkins MK, Schwartz RH (1989) Clonal expansion vs functional clonal inactivation: a costimulatory signalling pathway determines the outcome of $\mathrm{T}$ cell antigen receptor occupancy. Annu Rev Immunol 7:445

17. Oettgen HC, Terhorst C, Cantley LC, Rosoff PM (1985) Stimulation of the T3-T cell receptor complex induces a membranepotential-sensitive calcium influx. Cell 40:583

18. Oi VT, Morrison SL (1986) Chimeric antibodies. Biotechniques 4:214

19. Ortho Multicenter Transplant Study Group (1985) A randomized clinical trial of OKT3 monoclonal antibody for acute rejection of cadaveric renal transplants. N Engl J Med 313:337

20. Pichler WJ, Walker C, Bettens F, Koponen M, Von Tscharner V, Kurrle R, Snow C, DeWeck AL (1987) Differences of T cell activation by the anti-CD3 antibodies Leu4 and BMA030. Cell Immunol 108:175

21. Poenie M, Tsien RY, Schmitt-Verhulst A-M (1987) Sequential activation and lethal hit measured by $\left[\mathrm{Ca}^{2+}\right] \mathrm{i}$ in individual cytolytic $\mathrm{T}$ cells and targets. EMBO J 6:2223

22. Pupa SM, Canevari S, Fontanelli R, Ménard S, Mezzanzanica D, Lanzavecchia A, Colnaghi MI (1988) Activation of mononuclear cells to be used for hybrid monoclonal antibody-induced lysis of human ovarian carcinoma cells. Int J Cancer 42:455

23. Pupa SM, Canevari S, Colzani E, Damgard EM, Ménard S, Miotti S, Colnaghi MI (1991) Purification of bispecific monoclonal antibodies produced by a hybrid hybridoma. J Immunol Res 3:16

24. Rabinovitch PS, June CH, Grossmann A, Ledbetter JA (1986) Heterogeneity among $\mathrm{T}$ cells in intracellular free calcium responses after mitogen stimulation with PHA or anti-CD3. Simultaneous use of indo-1 and immunofluorescence with flow cytometry. J Immunol 137:952

25. Renner C, Pfreundschuh M (1995) Tumor therapy by immune recruitment with bispecific antibodies. Immunol Rev 145:179

26. Renner C, Jung W, Sahin U, Denfeld R, Pohl C, Trümper L, Hartmann F, Diehl V, van Lier R, Pfreundschuh M (1994) Cure of xenografted human tumors by bispecific monoclonal antibodies and human T cells. Science 264:833

27. Rigley K, Slocombe P, Proudfoot K, Wahid S, Mandair K, Bebbington C (1995) Human p59fyn(T) regulates OKT3-induced calcium influx by a mechanism distinct from PIP2 hydrolysis in Jurkat T cells. J Immunol 154:1136
28. Roosnek E, Lanzavecchia A (1989) Triggering T cells by otherwise inert hybrid anti-CD3/anti-tumor antibodies requires encounter with the specific target cell. J Exp Med 170:297

29. Roosnek EE, Van Lier RA, Aarden LA (1987) Two monoclonal anti-CD3 antibodies can induce different events in human $T$ lymphocyte activation. Eur J Immunol 17:1507

30. Schwinzer R, Franklin RA, Domenico J, Renz H, Gelfand EW (1992) Monoclonal antibodies directed to different epitopes in the CD3-TCR complex induce different states of competence in resting human T cells. J Immunol 148:1322

31. Segal DM, Urch CE, George AJT, Jost CR (1991) Bispecific antibodies in cancer treatment. In: De Vita VT, Hellman S, Rosenberg SA (eds) Biologic therapy of cancer. Lippincott, Philadelphia

32. Spits H, Yssel H, Leeuwenberg J, De Vries JE (1985) Antigenspecific cytotoxic $\mathrm{T}$ cell and antigen-specific proliferating $\mathrm{T}$ cell clones can be induced to cytolytic activity by monoclonal antibodies against T3. Eur J Immunol 15:88

33. Tibben JG, Boerman OC, Claessens RAMJ, Corstens FHM, Van Deuren M, De Mulder PHM, Van der Meer JWM, Keijser KGG, Massuger LFAG (1993) Cytokine release in an ovarian carcinoma patient following intravenous administration of bispecific antibody OC/TR F(ab)2. J Natl Cancer Inst 85:1003

34. Tunnacliffe A, Olsson C, Traunecker A, Krissansen GW, Karjalainen K, De la Hera A (1989) The majority of CD3 epitopes are conferred by the epsilon chain. In: Knapp K, Dörken B, Rieber EP, Stein H, Gilks WR, Schmidt RE, Von dem Borne AEGK (eds) Leucocyte typing, vol IV: White cell differentiation antigens. Oxford University Press, Oxford, p 295

35. Valitutti S, Dessing M, Aktories K (1995) Sustained signaling leading to $\mathrm{T}$ cell activation results from prolonged $\mathrm{T}$ cell receptor occupancy. Role of T cell actin cytoskeleton. J Exp Med 181:577

36. Valitutti S, Müller S, Cella M, Padovan E, Lanzavecchia A (1995) Serial triggering of many T-cell receptors by a few peptide-MHC complexes. Nature 375:148

37. Vandenberghe PA, Ceuppens JL (1990) Flow cytometric measurement of cytoplasmic free calcium in human peripheral blood $\mathrm{T}$ lymphocytes with fluo-3, a new fluorescent calcium indicator. $\mathrm{J}$ Immunol 127:197

38. Van Wauwe JP, De Mey JR, Goossens JG (1980) OKT3: a monoclonal anti-human $\mathrm{T}$ lymphocyte antibody with potent mitogenic properties. J Immunol 124:2708

39. Wacholtz MC, Lipslky PE (1993) Anti-CD3-stimulated $\mathrm{Ca}^{2+}$ signal in individual human peripheral T cells. J Immunol 150:5338

40. Weiner GJ, De Gast GC (1995) Bispecific monoclonal antibody therapy of B-cell malignancy. Leuk Lymphoma 16:199

41. Weiss A, Imboden J, Hardy K, Manger B, Terhorst C, Stobo J (1986) The role of the T3/antigen receptor complex in T-cell activation. Annu Rev Immunol 4:593

42. Zhu Z, Carter P (1995) Identification of heavy chain residues in a humanized anti-CD3 antibody important for efficient antigen binding and $\mathrm{T}$ cell activation. Immunol 155:1903 